\title{
Sensory, microbiological, physical and chemical properties of cuttlefish (Sepia officinalis) and broadtail shortfin squid (Illex coindetii) stored in ice
}

\author{
Paulo Vaz-Pires ${ }^{\text {a,b,*, }}$, Pedro Seixas ${ }^{\text {a,b,1 }}$, Micaela Mota ${ }^{\text {a,b,1 }}$, Judite Lapa-Guimarães ${ }^{\text {c,2 }}$, \\ Jana Pickova $^{\mathrm{d}, 3}$, Andreia Lindo ${ }^{\mathrm{e}, 4}$, Teresa Silva ${ }^{\mathrm{e}, 4}$ \\ ${ }^{a}$ ICBAS - Instituto de Ciências Biomédicas de Abel Salazar, Universidade do Porto, Largo Prof. Abel Salazar, 2, 4099-003 Porto, Portugal \\ ${ }^{\mathrm{b}}$ CIIMAR - Centro Interdisciplinar de Investigação Marinha e Ambiental, Universidade do Porto, Porto, Portugal \\ ${ }^{\mathrm{c}}$ Departamento de Tecnologia de Alimentos, Faculdade de Engenharia de Alimentos, Universidade Estadual de Campinas, \\ CP 6121, CEP 13083-862, Campinas SP, Brazil \\ ${ }^{\mathrm{d}}$ Department of Food Science, Swedish University of Agricultural Sciences, P.O. Box 7051, 75007 Uppsala, Sweden

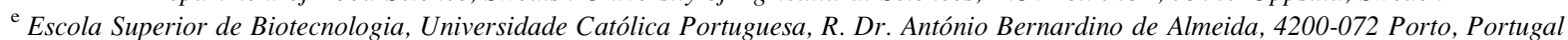

Keywords: Cephalopods; Sensory analysis; QIM; Microbial counts; RT-Freshmeter; Shortfin squid; Cuttlefish

\begin{abstract}
The objective of this study was to characterize whole raw cuttlefish (Sepia officinalis) and shortfin squid (Illex coindetii) during storage in ice through sensory, microbiological, chemical and physical analyses. The recently developed Quality Index Method (QIM) tables for these species were used for sensory analysis. Shelf-life of whole cuttlefish and shortfin squid were estimated as around 10 and 9 days, respectively, according to QIM, which is shorter than for most species, especially fish. The numbers of microorganisms found in cuttlefish and shortfin squid surfaces until rejection were lower than in fish, which suggest predominance of enzymatic (autolytic) degradation. $\mathrm{H}_{2} \mathrm{~S}$-producing bacteria constituted a significant proportion of the spoilage flora. Physical analysis performed using the RT-Freshmeter and the Torrymeter showed these instruments can be applied to cuttlefish and shortfin squid, providing useful complementary information on the rates of change of electrical properties. Free tryptophan and VBN contents significantly changed during the first storage week indicating that low levels of these compounds could be used as indicators of fresh and high quality cuttlefish and broadtail shortfin squid. Urea can be useful as spoilage indicator for cuttlefish, as well as agmatine for broadtail shortfin squid. An overall look into data obtained shows, as expected, that spoilage of these cephalopod species can be considered a different phenomena when compared to fish and is not yet completely clarified.
\end{abstract}

\footnotetext{
* Corresponding author. Instituto de Ciências Biomédicas de Abel Salazar, Universidade do Porto, Largo Prof. Abel Salazar, 2, Porto 4099-003, Portugal. Tel.: +351 222062272; fax: +351222062232.

E-mail address: vazpires@icbas.up.pt (Paulo Vaz-Pires).

1 Tel.: +351 222062272; fax: +351 222062232 .

${ }^{2}$ Tel.: +55 1935214015; fax: +55 1932893617 .

3 Tel.: +4618 672011; fax: +4618 672995 .

${ }^{4}$ Tel.: +351 225580001; fax: +351225090351.
}

\section{Introduction}

The world fishery production of cephalopods by major fishing areas has been estimated as 3346.8 metric tonnes in 2001 . Squid catches represented around $67 \%$ of total cephalopods fisheries, while octopus and cuttlefish accounted for 9.5 and $16 \%$, respectively (FAO, 2003). However, researchers suggested that the total world landing of cephalopods represents only a few percent of the potential resources (Guerra, 1991; Guerra, 1996; Sikorski \& Kolodziejska, 1986). Of the species that are explored world-wide roughly $41 \%$ belong to the 
genera Loligo, Sepia or Octopus, which are predominantly found on the continental shelf (Guerra, 1996).

The consumption of cephalopods has recently increased in countries that were not traditionally cephalopod consumers, mainly as chilled and frozen ready meals (Barbosa \& VazPires, 2004). General handling, processing, preservation and product properties of cephalopods, mainly based on squid which is the major cephalopod species produced, were published by Kreuzer (1984). Since then, there has been a great progress in marketing, quality assurance and freshness assessment of fish products, but there have been only few studies on cephalopods quality assessment, most of them being directed to squid and shortfin squid (Byun et al., 2000; Langille \& Gill, 1984; Lapa-Guimarães, Silva, de Felício, \& Guzmán, 2002; Ohashi, Okamoto, Ozawa, \& Fujita, 1991; Paarup, Sanchez, Moral, et al., 2002; Paarup, Sanchez, Peláez, \& Moral, 2002) and octopus (Civera, Grassi, \& Pattono, 1999; Ruíz-Capillas, Moral, Morales, \& Montero, 2002).

As fish and shellfish products are usually highly perishable, their sensory quality attributes decrease quickly after capture. The change in the external appearance of cephalopods, specially related to a decrease in the skin reddish brown colour and shine, has been used for primary quality evaluation (Ke, Burns, \& Woyewoda, 1984; Lakshmanan, Varme, \& Iyer, 1993). However, this information is controversial and some authors reported intensification and spreading of the pink colour of the skin with time, rather than the decline in skin colour (Lapa-Guimarães et al., 2002). Combined sensory and biochemical studies have been conducted by Ke et al. (1984) and Ke, Fierheller, and Lemon (1991), who elaborated a useful grading procedure for the species Illex illecebrosus based on its content of total volatile bases, trimethylamine and free fatty acids, previously correlated with sensory results.

Fish quality can also be assessed by using three different instruments that measure the changes in the electrical properties of the fish: the German instrument Intellectron Fish Tester came up in 1965 (Hennings, 1965), the Scottish Torrymeter that was marketed in 1970 (Burt, Gibson, Jason, \& Sanders, 1976), and the Icelandic RT-Freshmeter that was developed in 1985 (Martinsdóttir, 1987; Vaz-Pires, Araújo, \& Kirby, 1995). The immediate response of the electrical instruments is one of their advantages. Others are the easy use in routine measurements and the fact that they can be operated by nontrained personnel (Heia et al., 1997; Oehlenschläger, 2003; Ólafsdóttir et al., 1997) and do not imply the destruction of the samples. These instruments may be used to indicate the spoilage process and remaining shelf-life in whole fresh fish (Vaz-Pires et al., 1995).

Chemical indices for freshness evaluation of fish, crustaceans and molluscs are mainly based on changes of non-protein nitrogen (NPN) components during the storage, such as volatile basic nitrogen (VBN) and trimethylamine (TMA) (Lapa-Guimarães, de Felício, \& Contreras, 2005). TMA and VBN acceptability limits have been proposed for some squid species (Ke et al., 1984). Other studies (Civera et al., 1999; Paarup, Sanchez, Moral, et al., 2002; Romo, Astudillo, Munõz, \& Contreras, 1996) have shown that acceptable limits are dependent on the species and storage conditions, and thus, highly variable. In addition to the VBN analysis, the determinations of free tryptophan (Lapa-Guimarães et al., 2005; Romo et al., 1996) and urea (Lapa-Guimarães et al., 2005; Otsuka, Tanaka, Nishigaki, \& Miyagawa, 1991; Romo et al., 1996) have been evaluated as freshness indices in squid species, with promising results.

Only a small number of studies have enclosed sensory, chemical and microbiological changes in cephalopods, moreover, microbiological studies have mainly focused on total aerobic counts. A better perception of the spoilage mechanism could guide to methods for increasing shelf-life, which could encourage the marketability of fresh chilled squid (Paarup, Sanchez, Moral, et al., 2002).

The objective of this study was to characterize the sensory, microbiological, chemical and physical changes of cuttlefish and shortfin squid during iced storage and to determine the usefulness of some available methods for quality evaluation.

\section{Material and methods}

\subsection{Cuttlefish and shortfin squid source and storage}

Cuttlefish (Sepia officinalis) and broadtail shortfin squid (Illex coindetii) were purchased at the first sale auction market in Matosinhos fishing harbour, north of Portugal, from February 2004 to December 2005. Cuttlefish were caught along the coast of Portugal, between Porto and Aveiro, by artisanal boats using entangling (trammel) nets. Shortfin squid were caught by bottom trawling boats operating along the coast of Portugal, between Porto and Sesimbra. Animals of both species were placed inside plastic bags, surrounded by crushed ice in clean and insulated containers and transported from the market to the laboratory ( $1 \mathrm{~h}$ maximum). At the laboratory they were measured, weighed and briefly washed with tap water to remove the excess of ink. The cephalopods were then placed in boxes with crushed ice, with perforated bottom, to allow the drainage of melted ice to an empty box placed underneath to collect drained water. Cephalopods were finally covered with crushed ice. Boxes were stored at refrigeration temperature $\left(2 \pm 2{ }^{\circ} \mathrm{C}\right)$. Crushed ice was added daily as required to maintain cuttlefish and squid always surrounded by ice. In all this set of experiments ice was in direct contact with cephalopod's skin. A total of 40 whole raw cuttlefish with an average weight of $536 \mathrm{~g}$ (range 176-823 g) and 48 whole raw squid with an average weight of $193 \mathrm{~g}$ (range $63-577 \mathrm{~g}$ ) were used.

\subsection{Sensory evaluation}

A total of 40 whole cuttlefish and 48 whole shortfin squid were used for sensory evaluations. Cuttlefish and squid were classified by three experienced assessors at least every 2 days of storage, in a common seafood laboratory with all equipment and facilities needed to perform this kind of test, using the recently developed Quality Index Method (QIM) for cuttlefish and shortfin squid (Vaz-Pires \& Seixas, 2006). 


\subsection{Microbiological analysis}

Microbiological sampling was performed in three independent storage experiments for cuttlefish and two independent storage experiments for shortfin squid. A total of 17 cuttlefish and 9 squid were used exclusively for the microbiological experiments, as the manipulation necessary for the physical analysis is expected to induce contamination. Individual areas of around $10 \mathrm{~cm}^{2}$ of the surface of the mantle were swabbed with sterile cotton swabs. The swabs were then shaken in $10 \mathrm{ml}$ of cooled $1 / 4$ strength Ringer solution (Oxoid). Appropriate series of decimal dilutions were performed, from which surface inoculations were made using the $20 \mu$ drop method in four solid medium: Nutrient agar (NA, Oxoid), Iron agar (IA, according to Gram, Trolle, \& Huss, 1987), Pseudomonas agar (PA, Oxoid) and MacConkey agar (MCA, Oxoid). Total viable counts (TVC), selective counts of $\mathrm{H}_{2} \mathrm{~S}$-producing bacteria and Pseudomonas counts were performed after 3 days of incubation at $20^{\circ} \mathrm{C}$. MCA plates used to enumerate Enterobacteriaceae were incubated at $37^{\circ} \mathrm{C}$ for 2 days. Counts were performed in duplicate and expressed as $\log \mathrm{cfu} / \mathrm{cm}^{2}$.

\subsection{Physical analysis}

Four storage trials were carried out using a total number of 36 cuttlefish and 44 squid. Each specimen was taken from the ice box and daily evaluated with the GR Torry Fish Freshness Meter (Torrymeter) type 295 (Distell Industries, Scotland, UK) and the RT-Freshmeter type RT-2E (Rafagnatækni Electronics, Reykjavík, Iceland). These are instruments fitted with electrodes that take measures based on the electrical impedance of the skin. The electrodes were previously cooled and kept at refrigeration temperature by direct contact with ice, as recommended by manufacturers, and were cleaned with clean paper tissue between measurements to remove mucus, which could influence the subsequent readings.

For the Torrymeter, six different measurements were made on each side of the mantle (dorsal and ventral). Each measure was taken by touching the skin once and individual values were noted. For the Freshmeter, six different measures were taken from each side of the mantle (dorsal and ventral), with a minimum contact of time of $1 \mathrm{~s}$ for each reading, as this instrument is able to take a series of measurements per second of continuous contact (around 100).

\subsection{Chemical analysis}

At $0,3,7,10$ and 13 days of storage five squid and three cuttlefish were randomly sampled from the different trials, frozen and sent to the Food Science Department of the Swedish University of Agricultural Sciences in Uppsala for chemical analysis. Extracts of the cephalopod mantles free from proteins were obtained by homogenizing $10 \mathrm{~g}$ of minced cuttlefish or squid mantle with $20 \mathrm{ml} \mathrm{5 \%} \mathrm{trichloroacetic} \mathrm{acid} \mathrm{(TCA)} \mathrm{for}$ $1 \mathrm{~min}$ using an Ultra-Turrax homogeniser. The homogenate was centrifuged $\left(1200 \times \mathrm{g}, 4 \mathrm{~min}, 18^{\circ} \mathrm{C}\right)$ and the extract filtered in filter paper. The precipitate was washed twice with
$10 \mathrm{ml} \mathrm{5 \%} \mathrm{TCA,} \mathrm{centrifuged} \mathrm{and} \mathrm{filtered.} \mathrm{The} \mathrm{extracts} \mathrm{were}$ collected and diluted to $50 \mathrm{ml}$ with $5 \%$ TCA in a volumetric flask and kept refrigerated at $4{ }^{\circ} \mathrm{C}$ until required. Contents of non-protein nitrogen (Horwitz, 1980), trimethylamine (Murray \& Gibson, 1972), volatile base nitrogen (Howgate, 1976), urea (SIGMA kit Urea Nitrogen 535A), free tryptophan (Contreras \& Lapa-Guimarães, 1989) and biogenic amines (LapaGuimarães \& Pickova, 2004) were determined in these muscle extracts.

\subsection{Statistical analysis}

Results were evaluated by ANOVA, where the main effect was storage time. Average differences were evaluated by Tukey test or Mann-Whitney test when lack of homoskedasticity was detected. A least significance level at $P<0.05$ was used. Simple linear correlation (Pearson correlation) between some analyses was evaluated. These statistical analyses were performed using the STATISTICA software, version 6.0 (Stat Soft, Inc. 1995, Tulsa, OK, USA).

\section{Results and discussion}

\subsection{Sensory evaluation}

QIM data obtained using the schemes for the species tested are shown in Fig. 1.

Taking into consideration sensory data and considering also all other results obtained, that support this idea (see following figures) the rejection was found to occur at day 10 in ice for cuttlefish and day 9 for squid, mainly due to the presence of unpleasant odours that started to be perceptible at day 6 and

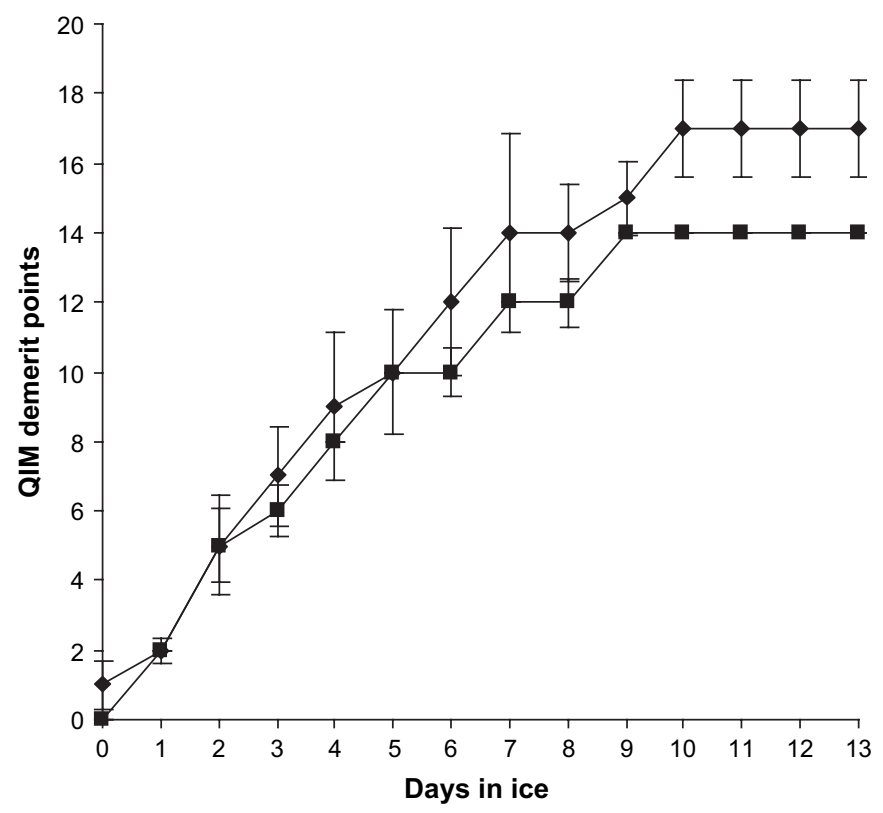

Fig. 1. Results obtained in sensory evaluation of iced cuttlefish Sepia officinalis $(\diamond)$ and broadtail shortfin squid Illex illecebrosus ( $)$ using the Quality Index Method (QIM) for 13 days of storage. Vertical bars represent standard deviation. 
were unacceptable at day 8 . These shelf-life results are similar to those found for octopus (Octopus vulgaris) (Hurtado, Borderías, Montero, \& An, 1999); cuttlefish (S. officinalis), musky octopus (Eledone moschata) and broadtail shortfin squid (I. coindetii) (Civera et al., 1999); common squid (Todarodes pacificus) (Yamanaka, Shiomi, \& Kikuchi, 1987); spear squid (Doryteuthis bleekeri) (Yokoyama, Takahashi, Sakaguchi, Kawai, \& Kanamori, 1994) and slender inshore squid or arrow squid (Loligo plei) (Lapa-Guimarães et al., 2002).

\subsection{Microbiological analysis}

Results from the microbiological analysis are presented in Fig. 2. All data shown represent mean of two different samplings from all individuals tested.
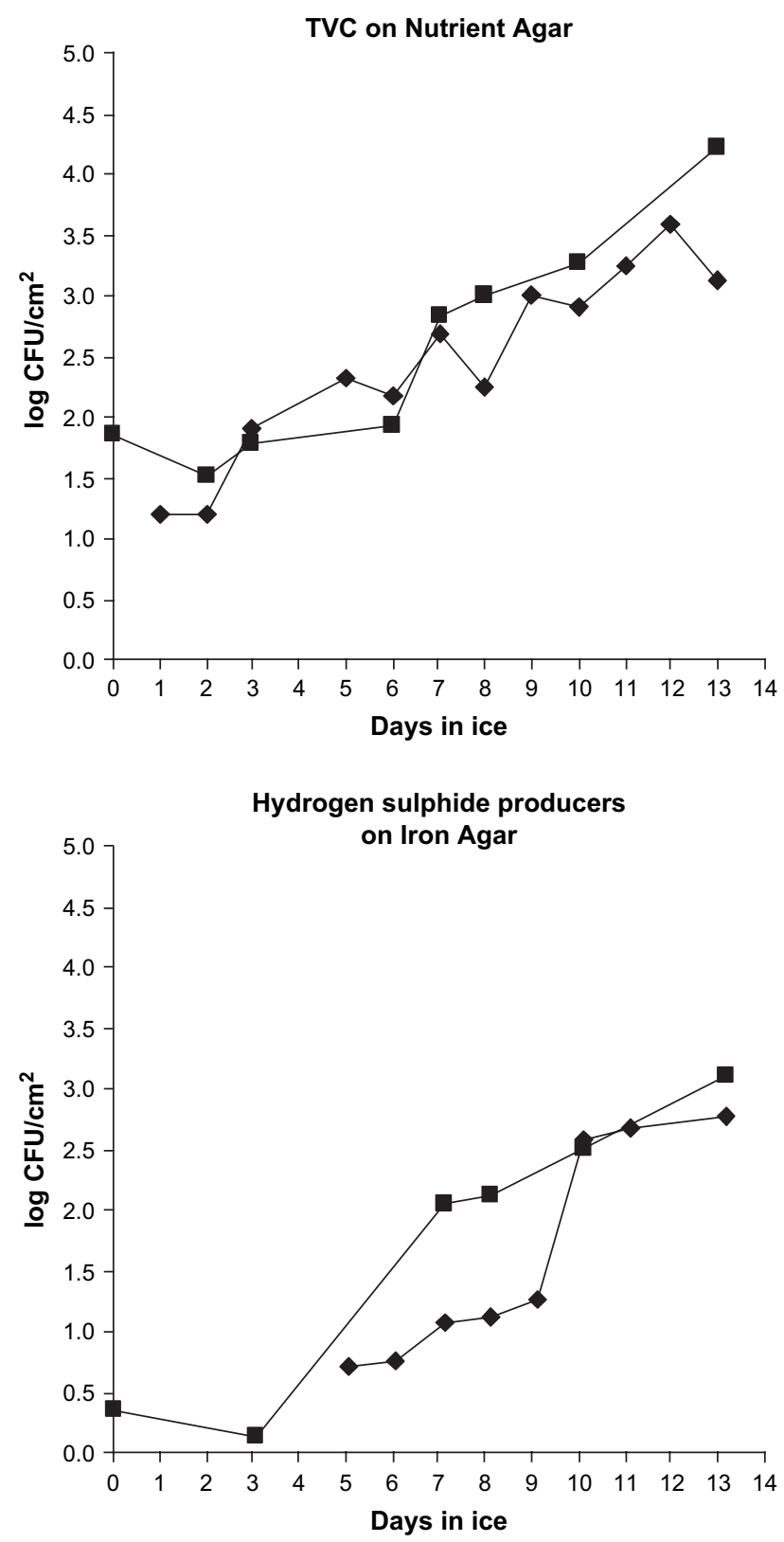

TVC on NA and IA were similar, but IA showed lower counts on days $2-7$. For both species, TVC analysis revealed an initial bacterial flora lower than $10^{2} \mathrm{cfu} / \mathrm{cm}^{2}$ and around $10^{3} \mathrm{cfu} / \mathrm{cm}^{2}$ at rejection (days 9-10). It is well known that the spoilage process in cephalopod molluscs is different from fish due, among many less clarified reasons, to thinner and fragile skin, nutritional composition much more favourable to enzymatic degradation, shorter and less pronounced rigor mortis, and initial autolytic degradation for a longer period (Hurtado et al., 1999; Vaz-Pires \& Seixas, 2006).

The results obtained in this work suggest that these differences exist and are normally observed. The relatively low number of spoilage bacteria (as measured in this work) at the point of rejection (which is around $10^{7}-10^{9} \mathrm{cfu} / \mathrm{g}$ for many fish and fish products) (Huss, Dalgaard, \& Gram,

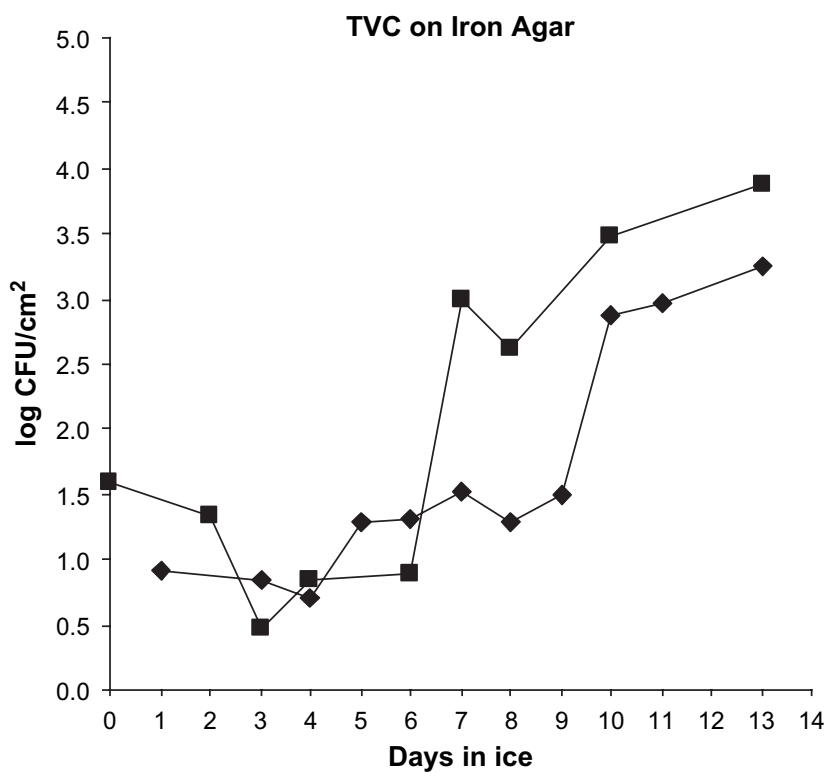

Pseudomonas Agar

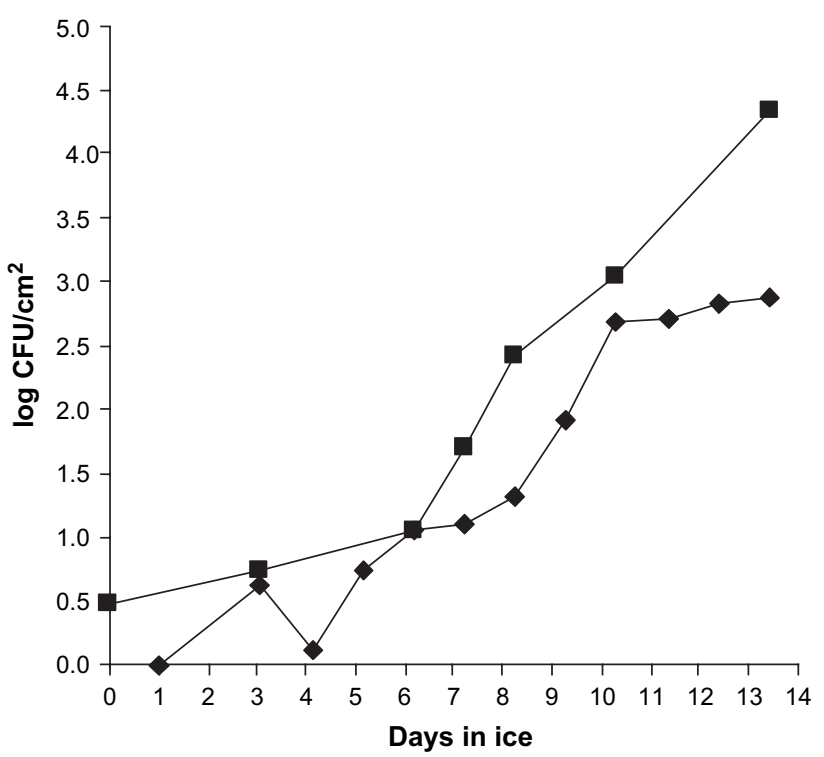

Fig. 2. Microbial results of iced cuttlefish Sepia officinalis $(\bullet)$ and broadtail shortfin squid Illex illecebrosus iron agar, counts of $\mathrm{H}_{2} \mathrm{~S}$-producers on iron agar and counts of Pseudomonas on Pseudomonas agar. 
1997; Ólafsdóttir et al., 1997) supports the common idea of the enzymatic action being more rapid and effective than putrefaction in cephalopods (Hurtado et al., 1999; Hurtado, Montero, \& Borderías, 2001; Lapa-Guimarães et al., 2002; Ohashi et al., 1991).

The general profile of the growth curve for $\mathrm{H}_{2} \mathrm{~S}$-producers on IA is similar to the TVC growth curve. $\mathrm{H}_{2} \mathrm{~S}$-producers represented a high proportion of the total spoilage flora, suggesting Shewanella putrefaciens, the most common sulphideproducer on fish tissues exposed to air, could be the main spoilage organism of these species, in this set of experiments.

The SSO grow without a lag phase and produce the metabolites responsible for spoilage (Dalgaard, 2002). This was clearly shown (and was expected) by the initial lower number of $\mathrm{H}_{2} \mathrm{~S}$-producers than total numbers in IA.

The numbers found on Pseudomonas agar were similar to the ones from both Nutrient agar and Iron agar, reaching around $10^{4} \mathrm{cfu} / \mathrm{cm}^{2}$ at days $9-10$. There are different salt concentrations in these media $(0.5 \% \mathrm{NaCl}$ in Nutrient agar and Iron agar, and no $\mathrm{NaCl}$ in Pseudomonas agar) and Paarup, Sanchez, Moral, et al. (2002), stated $\mathrm{NaCl}$ seemed to be a requirement for the growth of Pseudomonas and other bacteria associated with spoilage of marine species. The majority of the spoilage flora in cuttlefish and shortfin squid seems to be composed by Pseudomonas in this study.

Counts of Enterobacteriaceae on MacConkey agar are very low, never exceeding $0.5 \log \mathrm{cfu} / \mathrm{cm}^{2}$ for cuttlefish or being negligible until rejection for shortfin squid. General hygiene condition of the samples studied depends mainly on handling, which starts on board, and seems to be acceptable, taking into account the results obtained in this work.

Only a very restricted number of bacteria is able to penetrate in fish muscle during storage in ice, and this occurs only when the number of bacteria on the fish surface is higher than $10^{6} \mathrm{cfu} / \mathrm{cm}^{2}$ (Huss, 1998). In cephalopods, the enzymatic action is very rapid, which probably means microorganisms don't have enough time to penetrate in deep tissue layers.

From all microbiological analysis performed in this work, it can be concluded that, at least until sensory rejection, the microbial action is less evident than autolysis effects in cephalopods. The autolysis or the activity of endogenous enzymes was the main responsible for the change in sensory attributes. Microbial counts, as in other works with fish and with cephalopods, can still be considered useful additional data to follow the degradation process.

\subsection{Physical analysis}

The RT-Freshmeter (FM) and Torrymeter (TM) measurements were made separately on both sides of the cephalopods (dorsal and ventral), as no information was found on the recommended side. These data are represented separately in all graphs (Fig. 3).

For cuttlefish, values varied from around 10 to around 5, independently of the equipment, which is a range somewhat short when compared with FM values for other species (Vaz-Pires et al., 1995), even other cephalopods (Vaz-Pires
\& Seixas, 2006). All values for dorsal side of cuttlefish were lower than for ventral. This is probably connected with the different characteristics of both sides, as in the dorsal side the surface is harder and the skin more fragile, due to the presence of the internal bone near the surface. Due to the repeated contact of the electrodes, the integrity of the dorsal skin was partially lost at the end of the experiments. This fact leads to a recommendation for future work: measurements in cuttlefish should be taken only from ventral side.

The values for squid are somewhat different. For the FM values, higher slope and less difference between ventral and dorsal sides were observed. The TM obtained values with clear and growing difference between sides along degradation, but in this case higher values for dorsal side. This is in accordance with the idea of "less rigidity, better physical measurements" already discussed for cuttlefish: as both squid sides are less rigid, measurements show less difference between sides. The typical bi-phasic shaped curve observed for all species tested previously (Vaz-Pires et al., 1995) was not detected for the species in this study. This can be explained by the extremely short shelf-life of these cephalopods, in which the degradation phenomena seems to be essentially autolytic, leading to a first (enzymatic) phase so long that the second (microbiologically induced) cannot be observed or doesn't exist at all.

Although mean values previously obtained for octopus are much lower than those obtained from fish (Vaz-Pires, et al., 1995), for the species of cephalopods tested in this study values start to be relatively lower (for cuttlefish, around 9.5 for both instruments; for squid, around 10.0 for FM values and 8.0 for TM values), but remain more stable during all storage period (less decline). This fact also supports the generalized idea of more physical and chemical differences leading to more variability between cephalopod species than between fish.

Freshmeter and Torrymeter can be considered useful tools to assess the freshness of cuttlefish and shortfin squid, providing valuable complementary information especially valid during the first period of storage.

\subsection{Chemical analysis}

Results from the chemical analysis are shown in Fig. 4. The average concentrations of non-protein nitrogen (NPN) in shortfin squid and cuttlefish at day 0 were 789.6 and $371.2 \mathrm{mg} / 100 \mathrm{~g}$, respectively. Ruíz-Capillas et al. (2002) found NPN values considerably higher for squid, 1161 and $1182 \mathrm{mg} /$ $100 \mathrm{~g}$, in males and females, respectively.

The contents of NPN continuously decreased in both cephalopods during storage. After 7 days of storage, $30.4 \%$ of the NPN in cuttlefish and $47.6 \%$ in squid had been lost. Significant decreases $(P<0.05)$ in NPN were observed after 3 days of storage for squid and after 7 days of storage for cuttlefish. The effect of leaching on the NPN content during the iced storage of squids is well known. Raghunath (1984) verified that the NPN content decreased in the mantle of squid (Loligo duvauceli) while the NPN concentration increased in water derived from ice during $8 \mathrm{~h}$ of storage. Romo et al. (1996) 

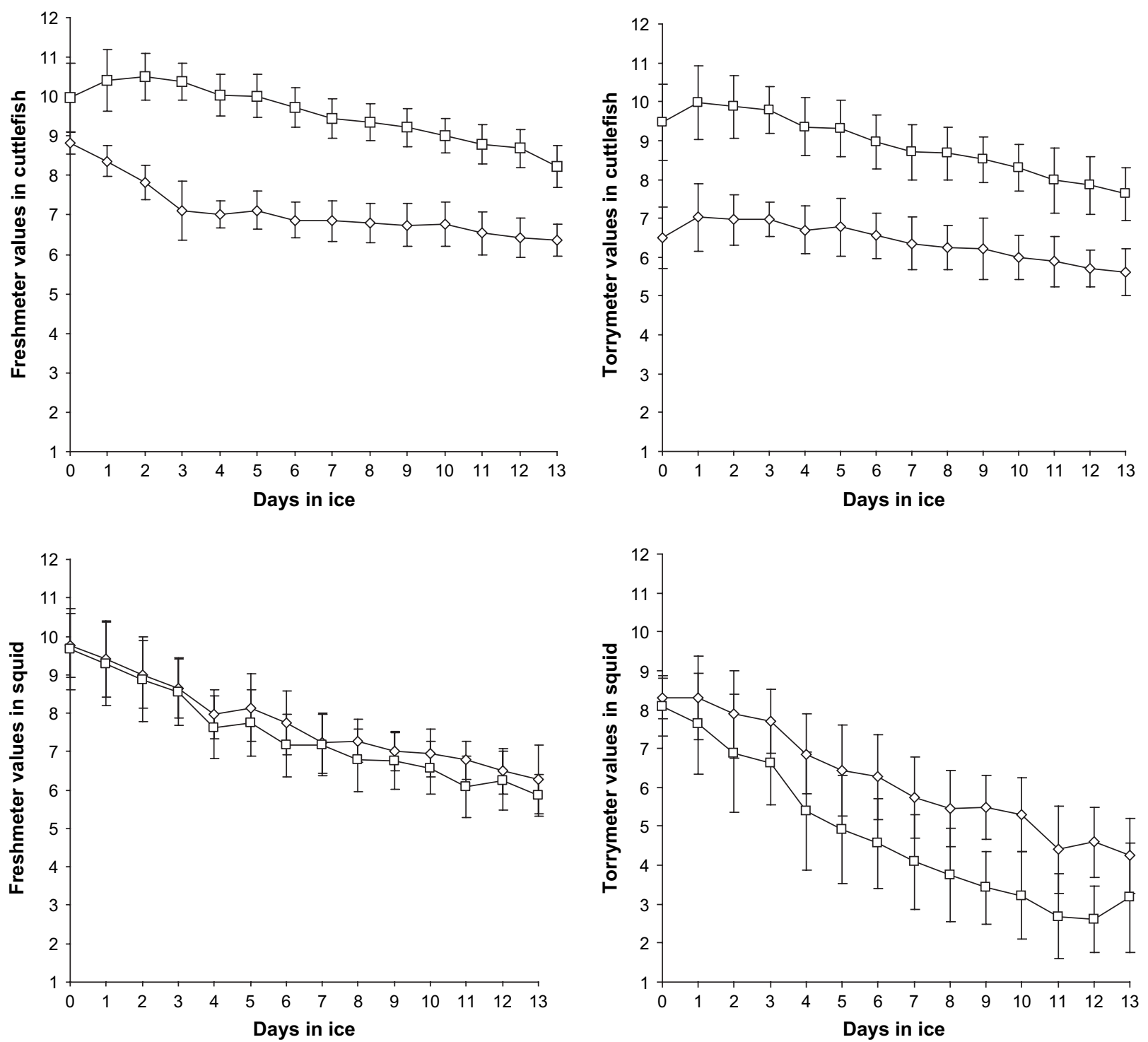

Fig. 3. Results obtained on physical evaluation of iced cuttlefish (Sepia officinalis) and broadtail shortfin squid (Illex illecebrosus) using the RT-Freshmeter and the Torrymeter. ( $\diamond=$ dorsal side of the mantle, $\square=$ ventral side of the mantle).

reported that squid (Dosidicus gigas) lost $40 \%$ of free amino acids after $72 \mathrm{~h}$ of storage in ice. In L. plei, $69.7 \%$ of NPN and $64.8 \%$ of the nitrogen from free amino acids were lost after 9 days of storage in contact with ice (Lapa-Guimarães et al., 2005). The leaching of soluble compounds can affect the efficiency of many chemical tests for freshness evaluation because increases of a soluble compound in the muscle will only be detected when the rate of its formation overcomes the loss rate.

In spite of the leaching shown by the NPN decreasing in both cephalopods in this study, an increase of all other compounds could be observed.

Fresh squid and cuttlefish showed 9.9 and $7.7 \mathrm{mg}$ of VBN/ $100 \mathrm{~g}$ muscle, respectively. These VBN values are lower than those detected in other cephalopods $24-36 \mathrm{~h}$ after capture (Lapa-Guimarães et al., 2005; Ruíz-Capillas et al., 2002), and indicate cephalopods of good quality and freshness. A continuous increase of VBN contents was observed in both cephalopods during the storage (Fig. 4). This VBN accumulation was less intense during the first week of storage and significant $(P<0.05)$ differences in relation to the first day were observed after 7 days of storage for both species (Mann-Whitney test for squid and Tukey test for cuttlefish). These results were similar to those found for other species of squids and cephalopods, in which the variations in VBN contents were small at the beginning of the storage. VBN has been considered useful as a spoilage indicator, having little use as a freshness index (Civera et al., 1999; Ohashi et al., 1991; Yamanaka et al., 1987). After 10 days of storage, the VBN contents in cuttlefish and squid were 21.9 and $26.9 \mathrm{mg} / 100 \mathrm{~g}$, respectively, indicating the production of VBN was more intense in cuttlefish.

The contents of trimethylamine (TMA) increased exponentially from 0.3 to $10.0 \mathrm{mg} / 100 \mathrm{~g}$ in cuttlefish and from 0.1 to $8.4 \mathrm{mg} / 100 \mathrm{~g}$ in shortfin squid after 13 days of iced storage. Due to the slow increase during the first week of storage, 

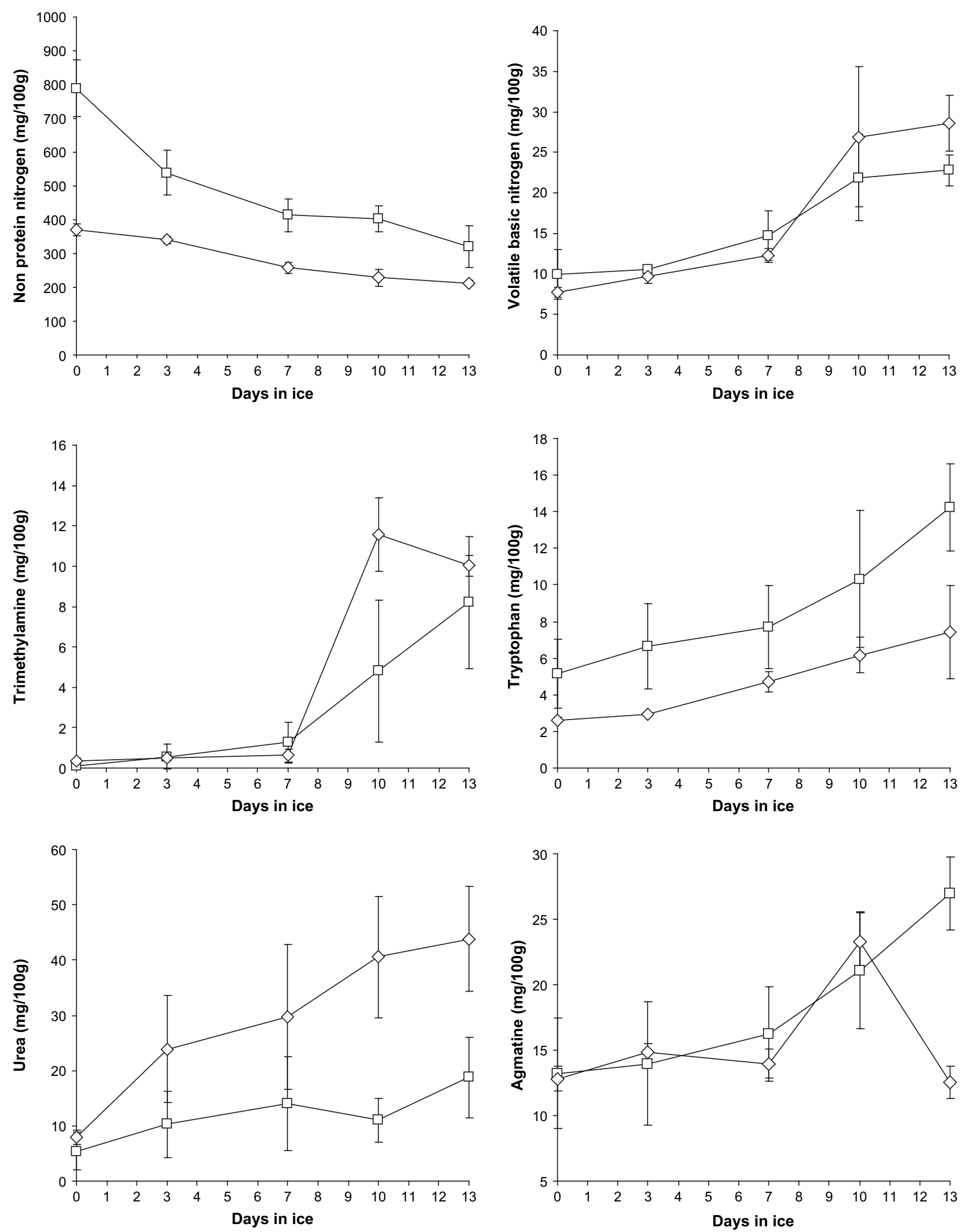

Fig. 4. Chemical results obtained on iced cuttlefish Sepia officinalis $(\diamond)$ and broadtail shortfin squid Illex illecebrosus $(\square)$ using quantifications of non-protein nitrogen, volatile basic nitrogen, trimethylamine, free tryptophan, urea and agmatine in muscular tissue. 
significant differences in TMA contents were observed only after 10 days of storage. Leblanc and Gill (1984) also detected an exponential production of TMA in I. illecebrosus squid stored at $2.5^{\circ} \mathrm{C}$. In L. plei TMA contents higher than $1 \mathrm{mg} /$ $100 \mathrm{~g}$ were found only after 12 days of iced storage (LapaGuimarães et al., 2005).

TMA production in fish and shellfish occurs due to the action of bacterial enzymes on the trimethylamine oxide (TMA-O). Although there are disagreements about the usefulness of TMA as freshness indicator for fish, Liston (1980) and Sikorski, Kolakowska, and Burt (1994) reported that the TMA production correlates well with the bacterial growth and, moreover, TMA is the main compound responsible for the smell of spoiled fish.

The fast increase of TMA and VBN (that includes TMA, other volatile amines and ammonia) from day 7 was certainly responsible for the unpleasant odours that started to be perceptible by the sensory assessors at day 6 and became unacceptable at day 8 for both cephalopods. This fact indicates that sensory rejection occurred when the bacterial effects on the cephalopods quality became more noticeable.

The urea content in squid increased from 5.4 to $18.8 \mathrm{mg} /$ $100 \mathrm{~g}$, but this increase was not continuous during the whole storage period. For cuttlefish, on the contrary, a continuous and intense accumulation of urea occurred, from $8.0 \mathrm{mg} /$ $100 \mathrm{~g}$ at the beginning of the storage to $43.8 \mathrm{mg} / 100 \mathrm{~g}$ after 13 days of storage. In spite of this markedly increase, due to the high standard deviation between animals, significant differences in relation to the first day were only detected after the first week of storage, suggesting that urea could be considered useful just as an indicator of low quality cephalopod. On the contrary, Otsuka et al. (1991) showed that the urea could be a good freshness index for squids of $D$. bleekeri species stored in plastic bags in ice, because the content of this compound increased gradually during the storage. For L. plei, increases of urea were only observed in samples stored without direct contact with ice (Lapa-Guimarães et al., 2005). It is clear that the leaching of soluble compounds during the storage in ice has a strong influence on the degree of urea accumulation, and consequently, in its usefulness as a quality indicator. Cephalopods are urotelic animals, thus it could happen a migration of urea from the viscera into the muscle during storage. However, increases of urea levels in muscle during storage were previously observed when only the muscle tissues of the squids D. bleekeri (Otsuka et al., 1991) and D. gigas (Romo et al., 1996) were stored in ice. These findings indicate that urea is, indeed, produced from other compound present in muscle during storage. One probable source for urea in cephalopods is the biogenic amine agmatine which can be broken down into putrescine and urea.

The contents of free tryptophan in fresh shortfin squid and cuttlefish were 5.1 and $2.6 \mathrm{mg} / 100 \mathrm{~g}$, respectively. The value found for cuttlefish was quite similar to that reported for L. plei $(2.9 \mathrm{mg} / 100 \mathrm{~g})$ (Lapa-Guimarães, 1999). There was a continuous increase of free tryptophan until $14.2 \mathrm{mg} / 100 \mathrm{~g}$ in squid and $7.4 \mathrm{mg} / 100 \mathrm{~g}$ in cuttlefish at the end of the storage. Considering only the first week of storage, significant
$(P<0.05)$ differences of tryptophan content were detected between days 1 and 7 for squid and between days 3 and 7 for cuttlefish. The increase of free tryptophan content in these cephalopods could only be explained by the occurrence of a relatively intense proteolysis during the iced storage, because it manifested despite the leaching. This occurrence had already been reported for the cephalopods D. gigas (Romo et al., 1996) and L. plei (Lapa-Guimarães et al., 2005).

The activity of decarboxylase enzymes produced by some bacteria over free amino acids leads to the production of biogenic amines. Putrescine, cadaverine, agmatine and tryptamine are the biogenic amines more frequently detected in cephalopods (Ohashi et al., 1991; Paarup, Sanchez, Moral, et al., 2002; Yamanaka et al., 1987). Agmatine, putrescine, cadaverine, spermine and spermidine were detected in squid and cuttlefish but only agmatine was present during the whole iced storage. The amino acid arginine is extremely abundant in free state in invertebrates (Ohashi et al., 1991; Yamanaka et al., 1987), in which it plays a role as phosphate source for ATP synthesis (Contreras, 2002). Agmatine can be easily formed from arginine decarboxylation, which could be an explanation for the predominant presence of agmatine in squid and cuttlefish since the beginning of the storage. On the other hand, the agmatine produced could be, subsequently, converted in putrescine, spermidine and spermine, making any increase less noticeable. Only in shortfin squid there was a progressive increase of agmatine during the whole storage period, but significant $(P<0.05)$ difference in relation to the first day was detected only by day 10 .

\section{Conclusions}

It can be concluded that $S$. officinalis and $I$. coindetii, as other foods of marine origin, can be evaluated using already-available sensory, microbiological, chemical and physical methods. But conclusions can only be drawn if the natural discrepancies, between fish and cephalopods and between different cephalopod species, are taken into account. Sensory analysis, as in other aquatic species, is the basic reference method, because it considers the consumer perceptions of the food quality. The spoilage process is somewhat different in cephalopods, in which the muscle tends to remain microbiologically less invaded until later than fish species, as spoilage seems to be dominated by autolysis until rejection. Instrumental methods like the RT-Freshmeter and the Torrymeter were used for the first time in cuttlefish and broadtail shortfin squid, and proved to be useful as a complement to the sensory data. Autolysis is probably one of the major factors influencing these instrumental readings. The production of VBN and TMA in S. officinalis and I. coindetii was well correlated with the sensory changes. The formation of free tryptophan in both cephalopods during the storage supports the occurrence of an intense autolysis process that leds until the breakdown of proteins. Significant changes in free tryptophan and VBN contents during the first storage week indicate that these compounds could be used as quality indicators for both species. Urea can be useful as spoilage index for $S$. officinalis, 
as well as agmatine for $I$. coindetii. Storage data indicate that cuttlefish and squid have shelf-lives (here defined as the time from death to rejection by sensory attributes) of around 9 days, much shorter than for other fish species but similar to other cephalopods.

\section{References}

Barbosa, A., \& Vaz-Pires, P. (2004). Quality Index Method (QIM): development of a sensorial scheme for common octopus (Octopus vulgaris). Food Control, 15(3), 161-168.

Burt, R., Gibson, D. M., Jason, A. C., \& Sanders, H. R. (1976). Comparison of methods of freshness assessment of wet fish. II. Instrumental and chemical assessment of boxed experimental fish. Journal of Food Technology, 11, 73-89.

Byun, M. W., Lee, K. H., Kim, D. H., Kim, J. H., Yook, H. S., \& Ahn, H. J. (2000). Effects of gamma radiation on sensory qualities, microbiological and chemical properties of salted and fermented squid. Journal of Food Protection, 63, 934-939.

Civera, T., Grassi, M. A., \& Pattono, D. (1999). Caractteristiche chimiche e microbiologiche di molluschi cefalopodi nel corso della conservazione. Industrie Alimentari, 38, 933-937.

Contreras, G. E. (2002). Bioquímica de pescados e invertebrados. Santiago de, Chile: Centro de Estudios em Ciência y Tecnologia de Alimentos. p. 309.

Contreras, G. E., \& Lapa-Guimarães, J. G. (1989). Determinação rápida de triptofano por reação com antrona. Congresso Brasileiro de Ciência e Tecnologia de Alimentos, 12, Rio de Janeiro. Livro de Resumos. Rio de Janeiro: SBCTA. p. 152.

Dalgaard, P. (2002). Modelling and predicting the shelf-life of seafood. In H. A. Bremner (Ed.), Safety and quality issues in fish processing (pp. 191-219). Cambridge: Woodhead Publishing Limited.

FAO. (November 2003). FAO Globefish Cephalopods Commodity Update. FAO.

Gram, L., Trolle, G., \& Huss, H. H. (1987). Detection of specific spoilage bacteria from fish stored at low $\left(0{ }^{\circ} \mathrm{C}\right)$ and high $\left(20^{\circ} \mathrm{C}\right)$ temperatures. International Journal of Food Microbiology, 4, 65-72.

Guerra, A. (1991). Cephalopod resources of the world: a present day view. In: The Second World Cephalopod Conference, November 11-13, Madrid, Espanha. Squid.

Guerra, A. (1996). Explotación mundial de cefalópodos. In: II Jornadas Internacionales sobre utilización de cefalópodos: Aspectos científicos y tecnológicos. Madrid, Espanha: Instituto del Frío.

Heia, K., Sigernes, F., Nilsen, H., Oehlenschläger, J., Schubring, K., \& Borderías, J., et al. (1997). Evaluation of fish freshness by physical measurement techniques. In G. Olafsdóttir, J. Luten, P. Dalgaard, M. Careche, V. Verrez-Bagnis, \& E. Martinsdóttir, et al. (Eds.), Methods to determine the freshness of fish in research and industry (pp. 347-357). Paris: International Institute of Refrigeration.

Hennings, C. (1965). The Intellectron Fish Tester V. In R. Kreuzer (Ed.), A new electronic method and device for the rapid measurement of the degree of freshness of wet fish (pp. 154-157). London: Fishing News Books.

Horwitz, W. (1980). Official methods of analysis of the association of official analytical chemists, (13th ed.). Washington D.C: AOAC.

Howgate, P. (1976). Determination of total volatile bases, TD 564. Aberdeen: Torry Research Station. Appendix 4.

Hurtado, J. L., Borderías, J., Montero, P., \& An, H. (1999). Characterization of proteolytic activity in octopus (Octopus vulgaris) arm muscle. Journal of Food Biochemistry, 23, 469-483.

Hurtado, J. L., Montero, P., \& Borderías, J. (2001). Chilled storage of pressurized octopus (Octopus vulgaris) muscle. Journal of Food Science, 66, 400-406.

Huss, H. H. (1998). El pescado fresco: su calidad y cambios de su calidad. [FAO Documento Técnico de Pesca No. 348]. Rome: Food and Agriculture Organization. p. 202.

Huss, H. H., Dalgaard, P., \& Gram, L. (1997). Microbiology of fish and fish products. In J. B. Luten, T. Børresen, \& J. Oehlenschläger (Eds.), Seafood from producer to consumer, integrated approach to quality (pp. 413-430). Amsterdam: Elsevier.

Ke, P. J., Burns, B. G., \& Woyewoda, A. D. (1984). Recommended procedures and guidelines for quality evaluation of atlantic short-fin squid (Illex illecebrosus). Food Science and Technology. [Lebensmittel-Wissenschaft und-Technologie], 17(5), 276-281.

Ke, P. J., Fierheller, M., \& Lemon, D. W. (1991). Studies on processing technology for atlantic short-fin squid (Illex illecebrosus). Food Science and Technology. [Lebensmittel-Wissenschaft und-Technologie], 24(4), 328-333.

Kreuzer, R. (1984). Cephalopods: handling, processing and products. FAO Fisheries Technical Paper, 254, p. 108.

Lakshmanan, P. T., Varme, P. R. G., \& Iyer, T. S. G. (1993). Quality of commercially frozen cephalopod products from India. Food Control, 4, $159-164$.

Langille, S. M., \& Gill, T. A. (1984). Postmortem metabolism of short-finned squid muscle (Illex illecebrosus). Comparative Biochemistry and Physiology, 79, 361-367.

Lapa-Guimarães, J. (1999). Estudos de índices químicos, sensoriais, microbiológicos e instrumentais para avaliação do frescor de lulas (Loligo plei, Bainville, 1823) armazenadas em gelo. Master thesis, Faculdade de Engenharia de Alimentos, Universidade Estadual de Campinas. p. 151.

Lapa-Guimarães, J., de Felício, P. E., \& Contreras, E. S. G. (2005). Chemical and microbial analyses of squid muscle (Loligo plei) during storage in ice. Food Chemistry, 91(3), 477-483.

Lapa-Guimarães, J., \& Pickova, J. (2004). New solvent systems for thin-layer chromatographic determination of nine biogenic amines in fish and squid. Journal of Chromatography A, 1045, 223-232.

Lapa-Guimarães, J., Silva, M. A. A., de Felício, P. E., \& Guzmán, E. C. (2002). Sensory, colour and psychrotrophic bacterial analysis of squids (Loligo plei) during storage in ice. Food Science and Technology. [Lebensmittel-Wissenschaft und-Technologie ], 35, 21-29. doi:10.1006/ fstl.2001.0783.

Leblanc, R. J., \& Gill, T. A. (1984). Ammonia as an objective quality index in squid. Canadian Institute of Food Science and Technology Journal, 17(4), 195-201.

Liston, J. (1980). Microbiology in fishery sciences. In J. J. Connell (Ed.), Advances in fishery science and technology (pp. 138-157). Surrey: Fishing News Books.

Martinsdóttir, E. (1987). Freshness measurements on cod and redfish with RT freshness grader. Reykjavík: Icelandic Fisheries Organization.

Murray, C. K., \& Gibson, D. M. (1972). An investigation of the method of determining trimethylamine in fish muscle extracts by the formation of its picrate salt. Part I. Journal of Food and Technology, 7(1), 35-46.

Oehlenschläger, J. (2003). Measurement of freshness quality of fish based on electrical properties. In J. Luten, J. Oehlenschläger, \& G. Ólafsdóttir (Eds.), Quality of fish from catch to consumer (pp. 237-249). Wageningen: Wageningen Academic Publishers.

Ohashi, E., Okamoto, M., Ozawa, A., \& Fujita, T. (1991). Characterization of common squid using several freshness indicators. Journal of Food Science, $56,161-163,174$.

Ólafsdóttir, G., Martinsdóttir, E., Oehlenschläger, P., Dalgaard, P., Jensen, B., \& Undeland, I., et al. (1997). Methods to evaluate fish freshness in research and industry. Trends in Food Science and Technology, 8, 258-265.

Otsuka, Y., Tanaka, S., Nishigaki, K., \& Miyagawa, M. (1991). Change in the contents of arginine, ornitine and urea in the muscle of marine invertebrates stored in ice. Bioscience Biotechnology Biochemistry, 56(6), 863-866.

Paarup, T., Sanchez, J. A., Moral, A., Christensen, H., Bisgaard, M., \& Gram, L. (2002). Sensory, chemical and bacteriological changes during storage of iced squid (Todaropsis eblanae). Journal of Applied Microbiology, 92, 941-950.

Paarup, T., Sanchez, J. A., Peláez, C., \& Moral, A. (2002). Sensory, chemical and bacteriological changes in vacuum-packed pressurised squid mantle (Todaropsis eblanae) stored at $4{ }^{\circ} \mathrm{C}$. International Journal of Food Microbiology, 74, 1-12.

Raghunath, M. R. (1984). Soluble nitrogen losses in squids (Loligo duvauceli) during storage in slush ice. Journal of Science and Technology, 21(1), $50-52$. 
Romo, C., Astudillo, J., Muñoz, O., \& Contreras, E. (1996). Determinación de índices bioquímicos y funcionales relevantes para evaluar la conservación de jibia (Dosidicus gigas) a bordo. Santiago. Proceedings of the workshop on fish and mollusc larviculture (pp. 197-213).

Ruíz-Capillas, C., Moral, A., Morales, J., \& Montero, P. (2002). Characterisation of non-protein nitrogen in the cephalopods volador (Illex coindetii), pota (Todaropsis eblanae) and octopus (Eledone cirrhosa). Food Chemistry, 76, 165-172.

Sikorski, Z. E., Kolakowska, A., \& Burt, J. R. (1994). Cambios bioquimicos y microbianos subsiguientes a la captura. In Z. E. Sikorski (Ed.), Tecnología de los productos del mar: recursos, composición y conservación (pp. 73-101). Zaragoza: Acribia, [Chap. 4].

Sikorski, Z. E., \& Kolodziejska, I. (1986). The composition and properties of squid meat. Food Chemistry, 20(3), 213-224.
Vaz-Pires, P., Araújo, I., \& Kirby, R. M. (1995). Physical measurement of the quality of fresh scad (Trachurus trachurus) and rainbow trout (Oncorhynchus mykiss) during ice storage using the RT Freshmeter. International Journal of Food Science and Technology, 30, 799-805.

Vaz-Pires, P., \& Seixas, P. (2006). Development of new quality index method (QIM) schemes for cuttlefish (Sepia officinalis) and broadtail shortfin squid (Illex coindetii). Food Control, 17, 942-949.

Yamanaka, H., Shiomi, K., \& Kikuchi, T. (1987). Agmatine as a potential index of freshness of common squid (Todarodes pacificus). Journal of Food Science, 52, 936-938.

Yokoyama, Y., Takahashi, S., Sakaguchi, M., Kawai, F., \& Kanamori, M. (1994). Postmortem changes of ATP and its related compounds and freshness indices in spear squid Doryteuthis bleekeri muscles. Fisheries Science, $60,583-587$. 